\title{
The Dagestani Security Paradigm in the View of Historical Perspective
}

\section{Juraj Hanuliak ${ }^{1}$}

Katedra politologie a evropských studí́, FF UP, Olomouc, Česká republika

The Dagestani Security Paradigm in the View of Historical Perspective. The paper is focused on the largest and ethnically most heterogeneous entity in the North Caucasus - Dagestan. After the consolidation of the security situation in neighboring Chechnya, Dagestan has become a primary security threat as well as a challenge of the North Caucasus region. Because of the ethnic and linguistic heterogeneity, the society based on primarily clan and tribal structures and weak local governments that cannot reasonably control the substantial part of the Dagestani territory, Dagestan has become an ideal base for an expansion of influence of radical Islam in the form of Wahhabism in the North Caucasus. Because of the spread of the Wahhabi ideology in Dagestan, terrorist attacks spread increasingly and the Dagestani society has become fragmented and disrupted. The paper is a case study aiming to describe and analyze the Dagestani security paradigm and its changes in the course of history, with emphasis on the neighboring actors influence.

Key words: Dagestan, Caucasus, Wahhabism, Clan, Russia, Islam

Dagestanská bezpečnostná paradigma $\mathbf{v}$ historickej perspective. Témou článku je rozlohou najväčšia a etnicky najheterogénnejšia entita v oblasti severného Kaukazu - Dagestan. Po skonsolidovaní bezpečnostnej situácie v susednom Čečensku sa práve Dagestan stal primárnou bezpečnostnou hrozbou, ale i výzvou severokaukazského regiónu. $V$ dôsledku etnickej a jazykovej heterogenity, spoločnosti založenej primárne na klanových a kmeňových štruktúrach a slabých lokálnych vládach, ktoré nedokážu reálne kontrolovat' značnú čast' územia, predstavuje Dagestan ideálnu základňu pre rozširovanie vplyvu radikálneho islamu vo forme wahhábizmu $v$ oblasti severného Kaukazu. V dôsledku šírenia wahhábistickej ideológie sa $v$ Dagestane čoraz častejšie odohrávajú teroristické útoky a sú narúšané vnútorné väzby $v$ spoločnosti, ktorá je čím d’alej tým viac atomizovaná a rozvrátená. Text je prípadovou štúdiou, jeho ciel'om je charakterizovat' a analyzovat' dagestanskú bezpečnostnú paradigmu a jej zmeny $v$ priebehu histórie, s dôrazom kladeným na influenciu susediacich aktérov.

Klúčové slová: Dagestan, Kaukaz, wahhábizmus, klan, Rusko, Islam

1 Address: PhDr. Juraj Hanuliak, Univerzita Palackého v Olomouci, Filozofická fakulta, Katedra politologie a evropských studií, Kř́ŕžkovského 12, 77180 Olomouc, Česká republika. 


\section{Introduction}

The Caucasus has always been is a borderline separating two worlds - Europe and Asia - not only in the geographical, cultural, ethnic and religious senses, but as a historical border as well. After all, even mythical Colchis, a mysterious, enigmatic and faraway country where Jason with the Argonauts came to acquire the Golden Fleece, was located in the area of present-day Georgia. This fact, however, can be seen from a different context as the Caucasus connects Europe with Asia, the Black and the Caspian Seas, North and South, and Islam with Christianity. The view that we receive is only a matter of our perspective.

The Caucasus, located on the border of two continents and during the history on the borders of kingdoms and empires, naturally became an object of their economic and geopolitical interests and expansive tendencies. In this area that is very important from geopolitical and geostrategic points of view, various entities have constantly been fighting for power and influence. However, Tsarist Russia, Turkey, Persia and others did not attempt to conquer this region only militarily, but they tried to implement their culture and patterns of civilizations (in terms of cultural and social anchors and identity) and to create a kind of civilizational mission. Because of the impact of these various entities, the Caucasus has become one of the world's most heterogeneous regions. In this case, moreover, ethnic heterogeneity is combined with religious and linguistic heterogeneity and this mixture creates a unique and rare geographical, social and political situation. This diversity is of benefit, but it can be a potential source of permanent tensions and instability in society as well. The amount of internal political actors - from clans, through religious authorities and ethnic groups to weak regional governments together with the imperial ambitions of great powers - has transformed the Caucasus into a "powder keg". In this very case, the situation in the $21^{\text {st }}$ century is not different from that in the $19^{\text {th }}$ or $20^{\text {th }}$ centuries. Security problems are visible nowadays in the south as well as in the north sides of the the Caucasus massif. However, the Caucasus mountain range creates a boundary within the Caucasus region itself and divides it into two essentially separate physical-geographical and socio-cultural units - the North and the South Caucasus. Due to the partly different historical development, they differ from each other by its ethnic and confessional structures and cultural and historical memories of the population as well as by the perception of its place and anchor in the globalizing world that is based on their different geopolitical paradigms and history. Simultaneously, on both the southern and northern sides of the Caucasus, there are permanently present more or less tense conflicts that have made of this 
region one of the world's most conflict areas in the geopolitically extremely important and fragile part of the world.

The paper deals with the North Caucasus as a geographic, cultural and socio-political region, and particularly with the largest and ethnically most heterogeneous entity in this region - the Republic of Dagestan. During the last 20 years, Dagestan has become a very serious security threat as well as a challenge. This position has been taken over from Chechnya, where after two bloody wars the situation is relatively consolidated nowadays due to the criminal authoritarian government of President Ramzan Kadyrov. In neighboring, ethnically extremely heterogeneous Dagestan, where society and elites are still primarily based on a clan structure, militant Islamists found a perfect base from which they could wage their "holy" war, leading to the establishment of the Caucasus Emirate. Some factors have to be taken into consideration, such as unstable and weak local governments unable to consolidate their power and gain control over the entire region along with their inability to control and guarantee border security, as well as penetration of the Dagestani territory by Islamic militants from neighboring Chechnya and Ingushetia that is constantly supported by massive export of Wahhabi ideology and Islamic mercenaries personally and financially supported by Saudi Arabia. All these factors have created an alarming security situation in Dagestan, which resulted in the increasing number of suicide terrorist attacks that nowadays take place even in the capital city of Makhachkala, as well as in an exponentially deteriorating security situation in the region as a whole.

We believe that the factor of Dagestan, or the security situation in this republic, is an absolutely crucial element that determines both the level and quality of security situation throughout the Caucasus region. Research of this region and its security situation is therefore more important than ever. Dagestan is too big, too potentially rich and has a too big geo-strategic importance to let it become an inherently unstable base for Islamic militants. But because Dagestan is so ethnically and socially heterogeneous, political and social ties in the Dagestani society are so complicated and complex that to address security matters and social problems as well as to achieve a stable and stabilized security situation approximates an attempt to address the squaring the circle in this region.

If we want to describe and analyze the security situation in Dagestan and its solution realistically, it is necessary to perceive this issue from a historical perspective, because the answers to many current fundamental questions lie in the history of this region. Without our knowledge of the history of Dagestan, we cannot legitimately consider the Dagestani presence and current situation as well as the problems. In this paper, we are postulating and testing a hypothesis that "Dagestani security paradigm has been significantly changed over the time 
so in every period of Dagestani history it had a different basis and essence. This paradigm can be described as history centrist". The text is therefore primarily focused on the region's history, it briefly presents and characterizes the major historical stages of the region's development and the resulting nature of the local security paradigm (consisting in the primary issues and security factors as well as mutual relationships between actors), and it is also trying to draw possible outcomes and parallels to the current development.

The text is divided into three main chapters. The aim of the first chapter is to briefly introduce the Republic of Dagestan from the geographic, ethnic, confessional and socio-economic points of view. The second chapter is focused on the issue of cultural memory of the Dagestani society and its brief characterization. The last chapter is aimed directly on the changes of the Dagestani security paradigm through the development of Dagestan during its history (it is an analysis of the historical context).

The aim of this paper is to describe and analyze the Dagestani security paradigm, focusing particularly on the influences of the neighboring actors, and to answer the research question of how factors such as historical experience, cultural memory of the Dagestani population and the relationships with the extraterritorial entities have influenced or are still influencing the security situation in the republic. From a methodological point of view, this paper is a case study based on a combination of analytical and descriptive methods, depending on the dependent and independent variables and correlations between them.

The independent variables include:

1. the geographical location of Dagestan,

2. the heterogeneous structure of the Dagestani population,

3. the factor of Islam as a unifying element of the Dagestani society, an instrument of permanent resistance and distinguishing it from the outside actors,

4. the cultural memory of the Dagestani population,

5. the factor of Russia.

Under dependent variables, we understand:

1. the overall security situation in the region,

2. the permanently tense relations between the center (Moscow) and the periphery (Dagestan),

3. the export of radical Islam, mainly of the Wahhabi tendencies into the

Dagestani society,

4. the alarmingly deteriorating security situation in the region,

5. the socio-economic and social problems, resulting in the breakdown of traditional social structures. 
The text is based primarily on secondary information sources monographies and articles published in scientific journals. For example, the work of Galina M. Yemelianova, "Islam and Nation Building in Tatarstan and Dagestan of the Russian Federation" (1999), the paper by Jana Sackman Eaton, "The Russian Federation Islamic Republic of Dagestan: Curricular Decentralization, Social Cohesion and Stability" (2005), as well as "Ethnic Parity and Democratic Pluralism in Dagestan: A Consociational Approach" (2001) by Robert Bruce Ware and Enver Kisriev.

This paper has a limited scope and is designed only as a short, very incomplete and elementary introduction to the topic. However, we managed to articulate a number of interesting issues and problems that might be a good subject for further research and possible publishing in relation to this topic.

\section{Dagestan as a Region}

Dagestan, officially the Republic of Dagestan ${ }^{2}$, is a federal self-governing entity of the Russian Federation, located in the North Caucasus, near the geographic boundary of Europe and Asia. In terms of the inner security situation it is a very unstable region as a whole affected by escalating tensions and terrorist attacks nowadays. Dagestan is the largest and also ethnically most heterogeneous North Caucasus republic. It is a southernmost federal entity of the Russian Federation as well. Its territory with a total area of $50,300 \mathrm{~km} 2$ has about 2.9 million inhabitants, divided into more than 30 main ethnic groups (gks.ru 2010). Capital city is Makhachkala, located on the coast of the Caspian Sea, rich in oil and gas.

Geographically, Dagestan borders with predominantly Christian Georgia in the southwest, with Chechnya ${ }^{3}$ in the west, and in the northwest, Dagestan reaches the Stavropol Krai, another federal administrative unit of the Russian Federation with a high percentage of the population claiming allegiance as successors to the traditions and historical legacy of Cossacks, and the Republic of Kalmykia ${ }^{4}$. In the east, Dagestan borders with the Caspian Sea, and in the south, it borders with the massif of the Caucasus and with Shia Azerbaijan.

The location of Dagestan is geographically and geopolitically very convenient, and it has always been of explicit importance for Moscow. The Dagestani territory connects Europe with Asia and the Black and Caspian Seas

\footnotetext{
${ }^{2}$ The name of "Dagestan" has a Turkic-Persian origin. Linguistically it is derived from the Persian suffix "stan", which means "country", and the word "dag", meaning "mountain". Thus, in free translation, "Dagestan" means "country of mountains", which is a very accurate appelation.

${ }^{3}$ This border is a frequent target for Islamic fundamentalists.

${ }^{4}$ The only predominantly Buddhist administrative unit of the Russian Federation.
} 
as an axis, and allows the Russian Federation to promote its geopolitical and economic interests in the region. On the other hand, Dagestan was one of the poorest federal entities of the Russian Federation a few years ago, with an alarmingly high level of unemployment of almost $80 \%$. Approximately $85-$ $90 \%$ of the budget revenues came from Russian subsidies as a form of economic injections and subsidies (Yemelianova 1999: 626, Ware 1999: 3 in Eaton, 2005: 61). However, the situation has changed in recent years due to the large mineral resources, especially oil and gas ones in the Caspian Sea. The capital of Makhachkala is changing rapidly due to the megalomaniac development projects funded by oil revenues.

Nevertheless, Dagestan is facing new political and economic problems due to these processes. The Dagestani elites became more corrupt than ever before. Economy and politics are based on a more or less wild, tribal base in this region. Under these circumstances, various political and economic entities, local political leaders and oligarchs together with various interest groups are closely connected. These political and economic actors constantly fight among themselves for power, adhering strictly to the Machiavellian principle that "purpose and end justify the means."

However, it is important to note that in the case of Dagestan, the social consensus has always been a key factor. The stability of Dagestan is explicitly depending on the ability of different groups and segments of society to achieve a deal: "Dagestani multiethnic political system is not only an expression of ethnographic heterogeneity, but is formed by a complex of relations for a centuries...stability of society depends on balancing force of clan elites and the ability of the central institution to agree with them." (Kisriev, Ware 2001: 107) The geographic location of Dagestan strongly affected its social heterogeneity and complexity, combined with the ethnic and confessional diversity. The ethnic map of this area confirms this fact. From more than 30 ethnic groups living in Dagestan, six have more than 100,000 inhabitants. These groups have a Caucasian, Altaic as well as Indo-European ethnic and linguistic origin (Sagramoso 2007: 684). The largest ethnic group are the Avars with more than 850,000 inhabitants according the last census in 2010, and making up more than $30 \%$ of the total Dagestani population. The Avars are not a homogeneous ethnic group, because they consist of several interconnected ethnographic and linguistic groups connected by the language, the region they are living in and the cultural traditions. The second most numerous ethnic group is the Dargins (members of the Kubachi and Kaitag ethnographic groups) with approximately 490,000 people, representing $17 \%$ of the population, followed by the Kumyks (431,000; approx. $15 \%$ of the population) living in the central part of Dagestan, the Lezgians living in the southern parts of Dagestan $(385,000 ; 13 \%$ of the population), the Laks $(161,000 ; 5.6 \%$ of the population), and finally the 
Tabasarans (118,000; approx. 4\% of the population). The ethnic Russians live predominantly in the capital of Makhachkala and in the contiguous area on the coast of the Caspian Sea as well as in the northern parts of the republic, making up approximately $3.5 \%$ of the population (perepis-2010.ru 2011) . Each of $^{5}$ these ethnic groups creates a kind of regional ethnic area in which a majority of the population is concentrated. ${ }^{6}$ The Avars inhabit mostly the south-western part of the territory, the Lezgians live in the south along the Azerbaijani border, and the Kumyks live predominantly in the central part of the territory. The ethnic separation has resulted in a rather original culture, traditions and customs of each ethnic group. Most importantly, Islam has become a factor of self-identification uniting the Dagestani society as a whole. The geographical location of Dagestan as well as its ethnic diversity has predefined the troubled security situation in the region, but it has also resulted in the neccessity to constantly and actively try to reach a consensus within the Dagestani society (Kisriev, Ware, 2001: 107).

From the religious point of view, according the 2012 sociological survey more than $83 \%$ of the population adhere to Islam. If we are talking about religious minorities, approximately $5 \%$ of the population claim allegiance to the Shia branch of Islam, $2.4 \%$ to Christianity (primarily ethnic Russian population professing Eastern Orthodox Church), 1\% to other Christian churches, and $2 \%$ belong to neopaganists. About $9 \%$ of respondents said they were „spiritually based, but not believers“, $2 \%$ were atheists and $0.6 \%$ were members of other religious groups or had not answered (sreda.org/arena 2013). More than $90 \%$ of Dagestani Muslims are Sunnis, specifically members of the Shafi'i school, and only the Nogais, living in the northern parts, belong to the Hanafi school. From this point of view, Dagestan and Chechnya are exceptions since the Shafi'i school is the major Islam school only in these two federal administrative units. In the case of other dominantly Sunni regions in the Russian Federation, the Hanafi school is the major religious branch (Matsuzato, Ibragimov 2005: 753). The nature of Dagestani Islam is very syncretistic, with a considerable inclination to the Islamic mysticism. More than $60 \%$ of the Sunni population adheres to Sufi Islamic orders - turuqs, mainly Naqshbandi, Shazali and Kadiri. Dagestan thus belongs to the Russian federation units with the highest percentage of Muslim population (ibid).

Religion is an absolutely crucial aspect of Dagestani society. As Amri Shikhsaidov notes: „It is clear that Islam has become one of the most important and influential factors of social and socio-political life in Dagestan. The situation in the region cannot be analyzed and we cannot understand it without

\footnotetext{
${ }^{5}$ Around 100,000 people.

${ }^{6}$ With the exception of the capital of Makhachkala.
} 
perceiving it through the prism and factor of religion. Political scientists characterize Dagestan as a 'most Islamic' federal entity of the Russian Federation, and this statement is not an exaggeration." (ca-c.org 2010)

From the economic point of view, 15 years ago a major part of regional budget incomes was created by agriculture (whether plant or animal production) and fisheries (ibid: 626). Nowadays, more and more finance comes from the oil and gas production.

\section{Cultural Memory of the Nation and Dagestani Society}

Historically, Dagestan is a region that has been settled permanently for several thousands of years and whose history is full of turbulent twists and frequent changes of power paradigm. Throughout its history, Dagestani society, culture, religion, as well as the overall ethnogenesis were influenced by several external invasions of foreign entities that tried to control this territory because of its important geo-strategic position. Each of these actors naturally changed Dagestani society, its customs, traditions and overall appearance of the community at all levels - from religion through ethical standards to culture.

This is the main reason, why history and its changes stay at the very centre of the Dagestani security paradigm.

During the first millennium before Christ, the present territory of Dagestan was part of so-called Caucasian Albania. A Persian invasion led by the Sasanian Empire followed by the turns of eras and from 6th -7 th centuries, Arabian tribes spread Islam into the area. ${ }^{7}$ The Russian influence began to spread as the Russian Empire of Cossacks gradually consolidated its power and extended its influence from the turn of the 18th and 19th centuries. Russia definitively confirmed its supremacy by the signing of Treaty of Gulistan in 1813 and the Treaty of Turkmenchay in 1828 with Persia (Yemelianova 1999: 608).

The main wave of Dagestani resistance to Russia was visible from the first half of the 18th century. This resistance was based partially on a nationalist basis, but Islam has become a factor and instrument through which the Dagestani population and its resistance to the Russian rule has permanently operated. Islam has become an instrument of basic self-determination of Dagestani society, the way of how it could identify itself and wage a "holy war" against Russia. It has always been a central aspect of the cultural memory of the population regardless its ethnicity. For such an ethnically heterogeneous society, it is very difficult to find a pattern of self-determination in the national awareness or ethnicity. In such a case, nationalism is simply not sufficiently

${ }^{7}$ The first Dagestani ethnic group that has been Islamized were the Laks converted from local polytheistic religions to Islam during the 8th century. 
strong enough to build on that any emancipation processes and efforts. Heterogeneous society must find or create another replacement for homogenization, find a way how to interconnect society, a common framework on which it could build its identity. Dagestani people have found such a pattern in Islam.

The resistance to the Russian dominance (sometimes weaker, but bloodier at other times, but still there) has permanently been present in Dagestani society for centuries. Along with this permanent resistance, Islam has constantly been an immanent factor for Dagestani society as a way of how to protected itself from the outside world. However, it is important to note that despite the fact that Dagestan is surrounded by areas with a different culture, there have never been serious tensions and conflicts between them, with the exception of occasional incidents, and the notable exception of Russia and Russians.

The same could be applied to the inter-ethnic tensions in Dagestani society. Unlike most other federal units of the Russian Federation, no Dagestani ethnic group has been privileged and built "above" any other for it to be favoured by the central government, what could be a reason for ethnic tensions and might potentially creat internal instability. Moscow has been clearly aware of the extreme heterogeneity and complexity of Dagestani society and did not want to unnecessarily destabilize the potential "powder keg" (Yemelianova 1999: 610). At the same time, however, the Moscow centre has always showed how to effectively manipulate with the ethnic identity of Dagestani ethnic groups and used this as a way of how to maximize benefits while minimizing efforts. Ware and Kisriev identified Dagestan due to its extreme ethnic heterogeneity, as a kind of "scale model or miniature of the Soviet Union, with all its problems, but also potential" (Kisriev, Ware, 2001: 110).

Ethnic heterogeneity created some kind of ethnic tolerance, but, on the other hand, the complexity of Dagestani society has resulted in the social and cultural closeness of this region. This situation has been strengthened by the forms of social-economic interactions in society, cultural traditions on which Dagestani society and its social mechanisms are established. Dagestani society is still based primarily on clans, combined with the already mentioned ethnicity. Each of the clans, traditionally called tukhum, unites a group of families that are interrelated by kinship - based on a patrimonial line that goes back to the earliest ancestor of the clan that is becoming not a real figure but a mythological one very often (Yemelianova 1999: 606). Clans are then united in larger units called djamaat that sometimes unite more than 30 clan units (Eaton 2005: 61). The djamaat is essentially a community, a conglomerate of politically organized units - municipalities, groups of municipalities, or clans (the above-mentioned tukhums), interconnected by territorial and historical ties. The djamaat is governed by a council of elders, in which each tukhum is 
represented by some representative. According to Ware and Kisriev, the djamaat is essentially an example of pre-consonsational, respectively preconsensual version of public policy, as it represents parity of all clan units and their representatives are making decisions by consensus (Kisriev, Ware, 2001: 109).

Besides Islam which is the uniting majority of the Dagestani population and Sharia law arising from it, every clan is governed by a conservative traditional code of ethic governing life of each clan and people at all levels, called adat Dagestani customary law. Dagestani society has naturally undergone its internal evolution like every other society. During this processes and through mechanisms we have allready mentioned, Dagestani society started to move during the $15^{\text {th }}$ century into a stage when every important decision and decision-making process as a whole was managed no more by autonomous clans units, but this process changed into an interaction inside the djamaat governed by a council of elders through adat customary law, which in turn contributed to the political and social integration and stronger ties in the community (Kisriev, Ware, 2001: 109). As already mentioned, Islam very strongly influenced this process, as it determined the cultural memory of the nation as a factor of self-recognition of Dagestani society. Originally, Islam in Dagestan was not based on the strict Wahhabi form widespread predominantly on the Arabian Peninsula. This form started to spread in this area primarily at the end of the 20th century and has had devastating effects on Dagestani society. Mystical Sufi tariqats deny integration of religion and politics into one unit, putting emphasis on tolerance and moral principles. As Ware and Kisriev mentioned in this context "Wahhabi puritanism and fully veiled women were totally engineered elements in Dagestan. These elements are in direct opposition to the free-spirited, egalitarian North Caucasus muslim authorities, with a positive relationship to the alcohol." (Kisriev, Ware, 2002: 8 in Eaton, 2005: 63)

Wahhabism is therefore an alien element for Dagestani society. At the end of the 20th century, especially in the 1990s, it has been expanded and penetrated society primarily due to disillusionment within the young generation which feels lost in the ever more sharply and rapidly changing world. During the first phase, Wahhabism had been imported into Dagestan from Saudi Arabia, which along with other Persian Gulf countries had largely supported (and it still does) the spread of radical Islam not only in the Caucasus region. During the second phase, after the Chechen wars and consolidation of the situation in Chechnya, Dagestan has started to be attacked by Islamist fighters directly from this area. Radical Islam offered at least some vision of the world and meaning of life for many people in this region, and it has become a kind of anchor, although totally distorted and sick. Many also hoped that due to the 
involvement in Islamic groups they would find at least partial financial and social benefits. The influence of Wahhabism on Dagestani society has become one of the most serious problems of Dagestan and a huge tragedy, because it has resulted in the loss and destruction of young generations and Dagestani society as a whole.

\section{Dagestani Security Paradigms}

As already mentioned, because of its geographic location in the geopolitically important region bordering powers and empires, as well as due to its heterogeneous ethnic structure, Dagestan has constantly been exposed to various security threats and risks, which determined the Dagestani security paradigms. They have naturally changed over time, but also have almost constantly been strongly influenced by one factor - the permanent presence of security threats (whether extraterritorial or internal) that affected Dagestan as a geographical and socio-economic area. In the case of the Dagestani security paradigm, we can identify two components or levels that create it:

1. The paradigm of security in relation to the external environment, entities and threats,

2. The paradigm of security determined by internal politics, economic and social characteristics, and society structure.

These two components have always influenced each other, though sometimes they blended and sometimes stood in sharp contradiction. However, they have never been completely separated, but permanently complementary in some sense. Also, of course, both have changed over time - the sources of extraterritorial threats, as well as the internal problems of the society and the risks that threatened its stability, have dynamically changed throughout history. If we want to evaluate and characterize the Dagestani security paradigms in terms of relation to the external environment or extraterritorial threats, the most appropriate way is to look at the history of Dagestan. In fact, it can be understood as a permanent succession to distinguish itself from the outside world and defense against all sorts of extraterritorial threats and entities, which threatened to destroy the Dagestani independence, autonomy, society, lifestyle, or anything else.

The oldest known state entity in this area was called Arran, in the ancient Parthian language known as Ardhan and in Armenian Ałuank'. In modern literature, this historic region is known as Caucasian Albania. An administrative center and also the most important city of this unit was Derbent, still one of the most significant Dagestani cities.

Caucasian Albania was established in the 4th century BC and collapsed in the 8 th century $\mathrm{AD}$, under the pressure of the surrounding entities. While the northern parts of Albania were ruled by mountain tribes (predominantly 
Avars), a major part of the territory came under the influence of Parthian and Sasanian Persia, and this territory was incorporated into the empire. This corresponds with the confessional paradigm of its population - predominantly Zoroastrian and later Christian (Maronite) Persia became the first major player, which fundamentally established the Dagestani security paradigm.

Both the situation and security paradigm changed in the 7th century, when massive invasions of Muslim Arabic tribes influenced this territory and gradually destroyed Sasanian Persia. Because of these processes, the territory of Dagestan disintegrated and the heterogeneous society based primarily on an ethnic base arised. Persia, as a key player in the Dagestani security paradigm, started to be replaced by Arabs together with their raids and civilizing missions, which consisted mainly in spreading Islam. Since the 8th century, the southern parts of Dagestan, affected in the social, cultural and confessional terms by Persia, were Islamized (Yemelianova 1999: 608). The security paradigm could therefore retain its north-south axis, but Persia was replaced by the impact of Arabs tribes. It also retained its geographic determinism and ongoing changes - the southern territories of Dagestan were Islamized as first and this new confessional line gradually moved towards the north.

The economic and military pressure of Muslims in the 12th century led to a gradual integration of areas under the control of Dagestani tribes into the Avar Khanate that controlled the western parts of today's Dagestan, inhabited primarily by the Avars from the 13th century to 1864. Due to the massive cultural, military and political influence of Islam from the south, most of the Dagestani population was Islamized by the $15^{\text {th }}$ century (ibid: 608-610). An important change took place in the 18th century, when the Russian tsar Peter the Great started to pay his attention to this region within the colonial ambitions of tsarist Russia as a great power. During the Russo-Persian War (1722-1723), known as Peter's Persian campaign, the Russian Empire defeated the Persian troops and by signing the Treaty of Saint Petersburg in 1723 formally annexed large areas of the Caucasus, including parts of today's Dagestani as well as Azerbaijani territory. Since this period, the civilizing mission of Russia in the North Caucasus can be observed. Russia has also become a third player in the Dagestani security paradigm until today. Nevertheless, the axis of the security paradigm has changed - for the first time, threat is coming not from the south, but from the north. Tsarist Russia, later the Soviet Union and the Russian Federation, has permanently influenced and tried to subjugate and homogenise the North Caucasus since the $18^{\text {th }}$ century. These efforts have always meant a new main adversary, a new type of threat, and a new factor and entity which Dagestan could oppose. After Persians and Arabs, Russians came (Matsuzato, Ibragimov 2005: 756). 
Since the last third of the $18^{\text {th }}$ century, but especially in the $19^{\text {th }}$ century, the "holy war" of Dagestani mountain tribes led by imams against the Russian rule and authority could be observed. Russia began to expand its influence by economic and military instruments. High taxation, forcible incorporation of Russian culture into the Dagestani society, as well as construction of a network of fortifications caused violent, defiant and permanent resistance of the Dagestani society to anything that was even remotely connected with Russia. In these processes, Avars and Dargins leading a permanent guerrilla war were most active. They created among themselves various inter-ethnic coalitions whose sole purpose was to fight against the Russian influence and domination. In 1785-1790, Shaykh Mansur Ushurma united numerous Dagestani and Chechen tribal communities, thus creating a form of military alliance against Russians. Other important persons of the Dagestani resistance were Muhammad Ghazi (Ghazi Mullah) and Gamzat-bek. But, undoubtedly, the most famous and influential figure of the Dagestani resistance was Imam Shamil, who established the Caucasian Imamate in 1834 as a final result of fights against Russia. Since then, the agenda of the Dagestani resistance against the Russian empire was significantly homogenized and institutionalized. The Existence of the Imamate in 1834-1859 meant the "golden age" of the Caucasian resistance to the Russian rule in the $19^{\text {th }}$ century (islamdag.info 2010). The Caucasian Imamate was essentially a theocratic and militaristic entity whose primary purpose was the defense of the Dagestani autonomy through permanent violent resistance to the Russian Empire. This was fully reflected in the Caucasian Wars, a protracted series of conflicts between the Russian Empire on the one side and the Caucasian Imamate together with historical Circassia (which is more or less corresponding with parts of today's North Ossetia and Krasnodar Krai) on the other. In most cases, the fights ended in 1859, after Imam Shamil had been forced to give up and interned under the house arrest in Kaluga, north-west of Moscow ${ }^{8}$. The conflicts continued to a lesser extent, primarily among the Circassians and the Russian imperial military troops until 1864, when the tsarist troops finally crushed the last resistance in this area (ibid).

In the mountainous regions of Dagestan, resistance activities were subsequently suppressed by tsarist troops in 1877-1878, thus the whole current Dagestani territory was incorporated into the Russian Empire (Yemelianova 1999: 609). A massive ethnic cleansing by the Russian institutions immediately followed. A large number of Adyghe people and members of other ethnic

${ }^{8}$ In 1870, Russian tsar Alexander II authorized the Hajj, an annual Islamic pilgrimage to Mecca to Shamil. A year later, Shamil died in Saudi Medina, where he was buried (islamdag.info 2010). 
groups professing Islam were forcibly and massively deported from the North Caucasus to the Ottoman Empire (King 2009: 94-96). These efforts regarding violent ethnic homogenization of this area are one of the most tragic episodes in the history of the Caucasus.

The 20th century brought ideologisation of the politics and fundamental changes into the geographical map of the world together with a new geopolitical paradigm. Through this point of view, the Dagestani security paradigm has been changing as well. As a result of World War I, the Russian Empire collapsed and the civil war between the Bolsheviks and the White Army begun. Each of the warring parties tried to exert its influence and interests in the Caucasus region because of its significant geostrategic position. The total political and social turmoil in Russia was subsequently used by the local Dagestani and Chechnian political and religious authority through declaration of the so-called North Caucasus Caliphate. This entity was, however, practically disintegrated in 1921 and destructed by Bolshevik forces, thereby becoming as the Dagestani Soviet Socialist Republic part of the USSR (Yemelianova 1999: 609-611). During the existence of the Soviet Union, internal security became a central point of the Dagestani security paradigm for the first time. The Soviet policy of forced transformation of the Dagestani demographic situation (the nature of settlement) and society, consisting in moving the whole mountain tribes in the lowlands areas, totally destructed the traditional form of the clan structure and fundamentally undermined the socioeconomic and social ties in society (ibid: 609). The second level became the wrong type of industrialization that was implemented. Because of poor economic policy, Dagestan's economic development decreased substantially and the country became one of the poorest regions of the USSR during the 20th century. We can therefore conclude that violent sovietization of the Dagestani society and economy, as well as social engineering by the Soviet authorities became the centre point of the Dagestani security paradigm within the USSR.

In the 1980s, autonomist emancipation processes started to be restored in Dagestan. These processes gained momentum after the collapse of the USSR in 1991-1992. In the case of Dagestan and its national efforts, it is necessary to re-define the basic problematic factor, which had fundamentally influenced these processes - the ethnic heterogeneity. Nationalism in Dagestan is unstable by its fundamental, highly diversified pattern. Each ethnic entity has its own subjective requirements, problems that it wants to solve, and needs that it wants to meet. These needs are often in direct conflict with the needs of other ethnic groups. The fundamental problem and axes of definition of the Dagestani nationalism is thus its heterogeneity, which subsequently weakens it internally. This is the reason why the Dagestani security paradigm did not change in the 1980s and 1990s - it stayed on the level of internal security, but transformed 
into a dispute about the overall nature of the Dagestani nationalism and its instruments, the form under which it will operate. This should be added as a factor of the increased centrifugal tendencies within the Dagestani society that arose by the secessionist tendencies of different ethnic groups, especially the Kumyks and the Lezgians. Through formation of separate autonomous units based on an ethnic key, the central Russian government promised various benefits to various ethnic groups. According to Vladimír Baar, this threatened with an escalation of inter-ethnic tensions, and the destabilization of society caused a very bad situation for the "Avars and other mountain ethnic groups, which would be cutted off from access to the Caspian Sea coast in the case of the establishment of independent Kumyk republic" (Baar, 2002: 134) The origin of the Lezgian Republic could turn into tensions erupting on the borders of Russia, as the Lezgians live in northern Azerbaijan (ibid). Dagestan and the North Caucasus as a whole form a geographical, social and economic periphery of the Russian Federation (Žídková 2012:18). But it is necessary to mention again that the cleavage between the centre (Moscow) and the periphery (North Caucasus) did not constitute the primary security threat in the 1980s and 1990s, but rather this security threat had roots directly in the Dagestani society and was created by such factors as the Dagestani nationalism, centrifugal tendencies within the society and the secesionist or autonomist aspirations of individual ethnic groups.

The last phase of the Dagestani security paradigm, which is now more topical than ever, is represented by penetration radical Islamism into Dagestan through an increasing influence of Wahhabi tendencies and radical Islamist groups in the Dagestani society. Yemelianova states that the first Wahhabis began to operate in Dagestan already in 1988. About 10 years later, in 1998, "three municipalities in the Bunyakski District (Karamakhi, Kabai-makhi and Kadar) declared themselves as islamic territory, governed by sharia law" (Yemelianova 1999: 612). During the 1990s, both the local government and religious authorities constantly tried to intervene against such tendencies. In 1997, a legislative act was adopted in the Dagestani parliament, which declared Wahhabi activities in the territory of Dagestan illegal. "Regulation on Direct Measures Against Religious Extremism" was adopted in this period as well (ibid).

The situation deteriorated seriously after the Second Chechen War was launched in 1999. In this year, groups of Islamic fundamentalists led by Shamil Basayev and Ibn al-Khattab invaded the Dagestani territory in order to establish an independent "Islamic State of Dagestan" in this area. During this period, the Dagestani police was able to affect Islamist groups relatively successfully and a majority of the Dagestani population stood against the attempts of Islamists. 15 years later, the situation changed radically. If we want 
to find reasons for the rise of popularity of Islamists and influence of radical Wahhabism in the Dagestani society, we need to look at the overall socioeconomic and social situation in the region. In this case, economy and social issues are directly connected or interdependent with the spread of radical Islam. In her work "The Russian Federation Islamic Republic of Dagestan: Curricular Decentralization, Social Cohesion and Stability", Jane Eaton Sackman notes that since 2000 it is possible to observe an increase of crimes in Dagestan, as well as the exponential increase of unemployment and economic hardship that hits a considerable part of society (Eaton 2005: 68). During the last 15 years, the amount of progressing economic, social and political problems resulted in a significant tendency of drifting young generation by the ideas of radical Islam. The penetration of Islamic insurgents and exportation of Wahhabi tendencies in the Dagestani territory has radically increased. Terrorist attacks are more frequent than ever and a constantly growing part of the population agrees with radical Islamism. Both the central government and political authorities are too weak and compromised to be able to fight with these negative trends.

In the current situation and conditions, there is only a small chance for a positive change. Such long-term processes could have been started only due to the substantial strengthening of the central institutions, cleansing of corruption and supporting the rule of law, not even to mention a change of conditions in the Russian Federation as a whole. Therefore, the risk of a negative scenario Dagestan becomes the center of radical Islamism in the Caucasus - is increasingly higher. At the crossroads between Europe and Asia, on the southern borders of the Russian Federation, lies a region that is internally totally destabilized. Moreover, this infection can spread further and further and destabilize the Caucasus region (Chechnya, Ingushetia, or even the south side of the Caucasus Mountain range) step by step. From the fragile ethnic conglomerate, which has been governed by finely balanced relations between clans and ethnic groups for centuries, Dagestan has become a base for Islamists leading their guerrilla war against the state institutions and civilian population. Nowadays, the Dagestani society is significantly destabilized and torn apart internally due to the influence of Wahhabism. If this trend continues, this process may end in a bloody civil conflict, or it will gradually intensify and result in a total disruption and destruction of the traditional clan and social structures. Just a few years from today and the Dagestani society could become a case of failed society, and Dagestan itself could become a collapsed federal unit that lost most of the entire young generation, a region in which the internal community ties and relations have been completely disrupted and destructed, with divided society in terms of social, intergenerational and inter-ethnic relations. 
Such is the nature and essence of the current Dagestani security paradigm the Dagestani society itself has become the biggest security threat to Dagestan due to the influence of Wahhabism. For centuries of Dagestani history, no extraterritorial threat so completely undermined the very essence of society linkages and relationships therein and the social and ethnic consensus, as a few years' effect of artificially imported Islamic ideology. Dagestan is therefore, unfortunately, destroying itself from within.

\section{Conclusion}

The security paradigm is constantly changing. Nothing is permanent, the world is in permanent motion. We illustrated this fact on the empirical case of the Dagestani territory.

If we identify the Dagestani security paradigms with the phases of historical development of that area, we obtained a relatively clear picture of the evolution of Dagestani security in relation to both security plans - extraterritorial and internal. Dagestani security has always been fundamentally dependent on the influence and activities of the surrounding entities. Activities of Persia, Arabic tribes, the Ottoman Empire and Russia in this area directly created rhe character of the security paradigm at its extraterritorial level.

As indicated in the text, in the case of the extraterritorial security level (based on the north-south axis), there are three elementary historical stages that created the Dagestani security paradigm. First, it is the period when the Dagestani territory was fundamentally influenced by Zoroastrian Sasanian Persia. From the 7th century, Arabic tribes played a role of the key entity in this area through the spreading of Islam. From the 18th century, the Russian Empire strengthened and fulfilled its imperial ambitions in this area. This confirms the key role of history in the Dagestani security paradigm, or its dependence and constant conversion based on historical cycles. This hypothesis can therefore be deemed confirmed. The influence of all of these actors fundamentally affected not only the level of security in the territory of presentday Dagestan, but also the nature of extraterritorial and internal conflicts. Spreading of civilizational patterns by all of these extraterritorial players naturally affected the nature of the Dagestani society, culture and religion. Persian has brought the impact of Zoroastrianism. Against ethnically heterogeneous Persia, which tried to unify and connect the heterogeneous ethnic and cultural world of many nations and ethnic groups within a single empire, the Dagestani society was built primarily on a clan and ethnic basis: in that period, it was an enormously autonomous and fragmented society. The Arab influence has brought a factor of Islam and a shift of confessional boundaries of Islam to the north. The main consequence of the civilizing mission of Arab tribes was a complete change of religion, confessional 
structure of the Dagestani society, and thus of its essence. Islam has become a tool for the unification of the society, which could not be homogeneous and consolidated on the basis of an ethnic or linguistic key. During this period, the cultural and collective memory of the Dagestani population and its patterns was created. Those patterns are not based on ethnicity, but together with the cultural framework, they are primarily based on religion.

he third extraterritorial player that created the Dagestani security paradigm was Russia in its various historical stages of development and forms of statehood, or the Russian factor from the 18th to the 21 st century. In Russia, the Dagestani people found entity against which they could define itself from the cultural and religious point of view.

Because of the Russian influence, the Dagestani security paradigm was radically transformed in the 20th century - it is no longer primarily extraterritorial, but internal. In other words, both the level and quality of the security situation in Dagestan were determined mainly by the internal political stability and economic and social problems, not by the extraterritorial impact of extraterritorial actors. A major threat for the stability of Dagestan today is not the cleavage line on the center-periphery axis, but the internal tensions inside the Dagestani society. An alarmingly high unemployment, the collapse of traditional social and political relationships and bonds that had worked for centuries, the loss of identity of the Dagestani society, corrupted and compromised local political elites - all these problems had created a fertile ground for the emergence of radical Wahhabism, which primarily penetrated into the Dagestani society and internally decomposed it since the late 20th century. Wahhabism and Islamism as all ideologies bring a destructive effect on society. Ideology starts where traditional links in society are weakened, its structure is increasingly fragmented, and a large part of society (especially the younger generation) feels more and more disconcerted, even uprooted from their lives. Then ideology comes and tries to fill this empty space, provides answers to questions, solves problems, articulates the basic vision of life meaning, a framework for life, sets social norms and rules, although they are almost always totally distorted. Exactly in this situation we can found the Dagestani society nowadays, standing on the brink of collapse for now. And precisely such is the current form of the Dagestani security paradigm, and the future development will likely move in similar intentions - the main security risk for current Dagestan is presented by its internally weakened, disrupted and polarized society.

\section{REFERENCES}

Arena, 2014. Atlas of Religions and Nationalities of the Russian. Available at: http://sreda.org/en/arena (1. 12. 2014). 
ca-c.org, 2010. Amri Shikhsaidov: Islam in Dagestan. Available at: http://www.cac.org/dataeng/06.shikhs.shtml (1. 12. 2014).

Russian Federal State Statistics Service, 2010. National Census 2010. Available at: http://www.gks.ru/free_doc/new_site/perepis2010/croc/perepis_itogi1612.htm (10. 12. 2014).

Islamdag.info, 2010. The Great Shamil, Imam of Daghestan and Chechnya, Shaykh of Naqshbandi Tariqah. Available at: http://www.islamdag.info/story/551 (10. 12. 2014).

Alekseev, M. A., 2001. Decentralization versus State Collapse: Explaining Russia's Endurance. In: Journal of Peace Research, vol. 38, no. 1, pp. 101-106. Available at: http://www.jstor.org/stable/425785.

Baar, V. 2002. Národy na prahu 21. století. Emancipace nebo nacionalismus? Ostrava: Tilia.

Baar, V., 2005. Decentralizační a dezintegrační procesy v Ruské federaci v 90. letech minulého století. Ostrava: University of Ostrava

Barrett, T. M., 1994. The Remaking of the Lion of Dagestan: Shamil in Captivity. In: Russian Review, vol. 53, no. 3, pp. 353-366. Available at: http://www.jstor.org/stable/131191.

Dunlop, J. B, 1998. Russia Confronts Chechnya. Roots of a Separatist Conflict. Cambridge: Cambridge University Press.

Eaton, J. S., 2005. The Russian Federation Islamic Republic of Dagestan: Curricular Decentralization, Social Cohesion and Stability. In: Peabody Journal of Education, vol. 80, no. 1, pp. 56-80. Available on: <http://www.jstor.org/stable/82624>.

Gorenburg, Dmitry, 2001. Nationalism for the Masses: Popular Support for Nationalism in Russia's Ethnic Republics. In: Europe-Asia Studies, vol. 53, no. 1, pp. 73-104. Available at: http://www.jstor.org/stable/826240

Ibragimov, M-R.; Matsuzato, K., 2005. Islamic Politics at the Sub-Regional Level in Dagestan: Tariqa Broterhoods, Ethnicities, Localism and the Spiritual Board. In: Europe-Asia Studies, vol. 57, no. 5, pp. 753-779. Available at: $<$ http://www.jstor.org/stable/30043949>.

International Crisis Group, 2008. Russia's Dagestan: Conflict Causses. Available at: http://www.crisisgroup.org/en/regions/europe/north-caucasus/192-russias-dagestanconflict-causes.aspx.

Hale, H. E.; Taagepera, R., 2002. Russia: Consolidation or Collapse? In: Europe-Asia Studies, vol. 54, no. 7, pp. 1101-1125. Available at: http://www.jstor.org/stable/826308 .

Hughes, J., 2007. Chechnya. From Nationalism to Jihad. Philadelphia: University of Pennsylvania Press.

King, Ch., 2009. The Ghost of Freedom. A History of the Caucasus. New York: Oxford University Press.

Kisriev, E.; Ware, R. B., 2001. Ethnic Parity and Democratic Pluralism in Dagestan: A Consociational Approach. In: Europe-Asia Studies, vol. 53, no. 1, pp. 105-131. Available at: <http://www.jstor.org/stable/826241>.

Kisriev, E.; Ware, R. B.., 2002. Irony and Political Islam: Dagestan's Spiritual Directorate. In: Nationality Papers, vol. 30, no. 4, pp. 1-28. Available at: 
http://www.siue.edu/ rware/Political_Islam_in_Dagestan.pdf .

Knysh, A., 2004. „Wahhabism“ as a Rhetorical Foil. In: Die Weld des Islams, vol. 44, no. 4, pp. 3-26. Available at: http://www.jstor.org/stable/1571334 .

Kugle, S., 2007. Sufis and Saints' Bodies: Mysticism, Corporeality, and Sacred Power in Islam (Islamic Civilization and Muslim Networks). Chapel Hill: University of North Carolina Press

Mamedov, M., 2008. „Going Native in the Caucasus: Problems of Russian Identity, 1801-64. In: Russian Review, vol. 67, no. 2, pp. 275-295. Available at: http://www.jstor.org/stable/20620748 .

Sagramoso, D., 2007. Violence and Conflict in the Russian North Caucasus. In: International Affairs, vol. 83, no. 4, pp. 681-705. Available at: $<$ http://www.jstor.org/stable/4541805>.

Waisová, Š., 2004. Od národní bezpečnosti k mezinárodní bezpečnosti. Kodaňská škola na křižovatce strukturálního realismu, anglické školy a sociálního konstruktivismu. In: Mezinárodní vztahy, vol. 39, no. 4, pp. 66-86. Available at: http://mv.iir.cz/article/view/124 .

Ware, R. B.; Kisriev, E.; Patzelt, W. J.; Roericht, U., 2003. Political Islam in Dagestan. In: Europe-Asia Studies, vol. 55, no. 2, pp. 287-302. Available at: http://www.jstor.org/stable/3594528 .

Yemelianova, G. M. 1999. Islam and Nation Building in Tatarstan and Dagestan of the Russian Federation. In: Nationalities Papers, vol. 27, no. 4, pp. 605-630. Available at: <http://ipac.kacst.edu.sa/eDoc/2006/158202_1.pdf >

Žídková, M., 2012. Proměny ruské imperiální politiky, Př́stup ruského centra k severnímu Kavkazu. Olomouc: Palacký University in Olomouc.

Juraj Hanuliak is PhD. candidate at the Department of Political Science and European Studies, Philosophical Faculty, Palacký University in Olomouc (field of study: Political Science) and PhD. candidate at the Department of Human Geography and Regional Development, Faculty of Science, University of Ostrava (field of study:Political and Cultural Geography). He graduated bachelors and masters degree of study of political science at the Department of Political Science, University of Ss. Cyril and Methodius in Trnava. Within political science, he is focusing on the Baltic region, theory of democracy, issues of non-democratic regimes and political geography.

PhDr. Juraj Hanuliak Univerzita Palackého v Olomouci

Filozofická fakulta Katedra politologie a evropských studií

Kř́ížkovského 12 77180 Olomouc Česká republika 